\title{
CORRECTION
}

\section{Correction to: Purification of dual-functioning chitinases with hydrolytic and antifreeze activities from Hippophae rhamnoides seedlings}

\author{
Bhavana Sharma $^{1} \cdot$ Ravi Gupta $^{2} \cdot$ Dinabandhu Sahoo $^{3} \cdot$ Renu Deswal $^{1}$ (I)
}

Published online: 24 April 2019

(c) Springer Nature Singapore Pte Ltd. 2019

\section{Correction to: \\ Journal of Proteins and Proteomics (2019) 10:69-81 \\ https://doi.org/10.1007/s42485-019-00007-9}

Unfortunately, an error occurred in Fig. 5. The corrected

Fig. 5 is given below.

The original article can be found online at https://doi.org/10.1007/ s42485-019-00007-9.

Renu Deswal

rdeswal@botany.du.ac.in; deswalr@hotmail.com

1 Molecular Physiology and Proteomics Laboratory, Department of Botany, University of Delhi, Delhi 110007, India

2 Department of Plant Bioscience, College of Natural Resources and Life Sciences, Pusan National University, Miryang, South Korea

3 Department of Biotechnology, Institute of Bioresources and Sustainable Development, Imphal, Manipur, India 


\section{(a) HrS CHT1a}

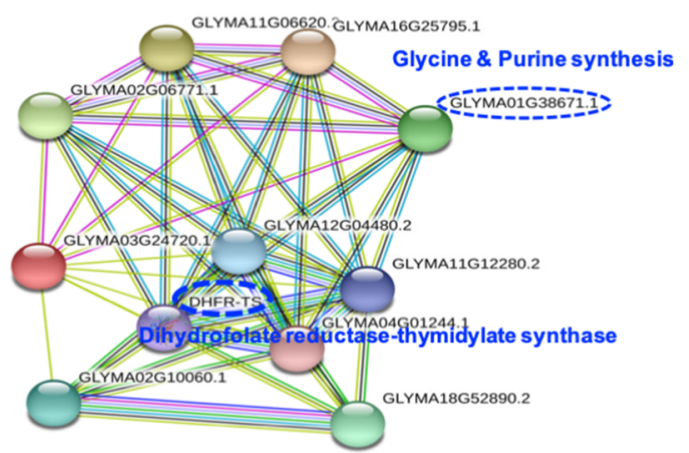

XP_006601470.1, uncharacterized protein

\begin{tabular}{cl}
\hline \multicolumn{1}{c}{ Identifier } & HrS CHT1a Interacting Partners \\
\hline DHFR-TS & $\begin{array}{l}\text { Bifunctional dihydrofolate reductase- } \\
\text { thymidylate synthase } \\
\text { Key enzyme in folate metabolism. }\end{array}$ \\
GLYMA04G01244 & $\begin{array}{l}\text { Denovo glycine \& purine synthesis, } \\
\text { DNA precursor synthesis }\end{array}$ \\
GLYMA11G06620 & $\begin{array}{l}\text { Denovo glycine \& purine synthesis, } \\
\text { Nucleotide metabolism }\end{array}$ \\
GLYMA04G06771 & $\begin{array}{l}\text { Denovo glycine \& purine synthesis } \\
\text { Nucleotide metabolism }\end{array}$ \\
GLYMA12G04480 & $\begin{array}{l}\text { Denovo glycine \& purine synthesis, } \\
\text { Nucleotide metabolism }\end{array}$ \\
GLYMA16G25795 & $\begin{array}{l}\text { Denovo glycine \& purine synthesis, } \\
\text { Nucleotide metabolism }\end{array}$ \\
\hline Growth & and Development responses \\
\hline
\end{tabular}

\section{(b) HrS CHT1b}

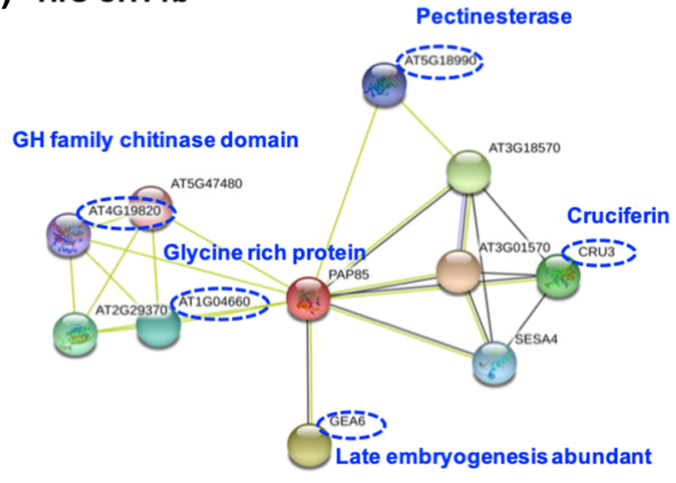

VCLA_PEA, Provicilin

\begin{tabular}{|c|c|}
\hline Identifiers & Hrs CHT1b Interacting Partners \\
\hline CRU 3 & Cruciferin : Seed storage protein \\
\hline GEA 6 & $\begin{array}{l}\text { Stress induced protein for dessication tolerance } \\
\text { Encode LEA gene in response to } A B A \text {. }\end{array}$ \\
\hline AT1G04660 & Glycine-rich protein \\
\hline AT4G19820 & Glycosyl hydrolase family protein with chitinase domain \\
\hline PAP85 & Cupin family protein; Seed storage protein \\
\hline $\begin{array}{l}\text { AT3G01570 } \\
\text { AT3G18570 }\end{array}$ & $\begin{array}{l}\text { Oleosin family protein; structural role to stabilize lipid body } \\
\text { during desiccation of seed. }\end{array}$ \\
\hline AT5G18990 & Pectinesterase : cell wall modification \\
\hline SESA4 & Seed storage albumin 4 ; a seed storage protein \\
\hline AT5G47480 & Protein export from endoplasmic reticulum to Golgi \\
\hline AT2G29370 & Tropine dehydrogenase \\
\hline
\end{tabular}

Fig. 5 In silico string analysis to identify the protein-protein interaction networks of purified chitinases HrS CHT1a and HrS CHT1b

Publisher's Note Springer Nature remains neutral with regard to jurisdictional claims in published maps and institutional affiliations. 